Santa Clara University

Scholar Commons

Accounting

Leavey School of Business

$12-2007$

\title{
Bankruptcy probability changes and the differential informativeness of bond upgrades and downgrades
}

Yongtae Kim

Santa Clara University, y1kim@scu.edu

Sandeep Nabar

Follow this and additional works at: http://scholarcommons.scu.edu/accounting

Part of the Accounting Commons

\section{Recommended Citation}

Kim, Yongtae, and Sandeep Nabar. "Bankruptcy Probability Changes and the Differential Informativeness of Bond Upgrades and Downgrades." Journal of Banking \& Finance 31.12 (2007): 3843-861.

NOTICE: this is the author's version of a work that was accepted for publication in Journal of Banking \& Finance. Changes resulting from the publishing process, such as peer review, editing, corrections, structural formatting, and other quality control mechanisms may not be reflected in this document. Changes may have been made to this work since it was submitted for publication. A definitive version was subsequently published in Journal of Banking \& Finance, Vol. 31, no. 12, (2007). doi:10.1016/j.jbankfin.2007.02.008.

This Article is brought to you for free and open access by the Leavey School of Business at Scholar Commons. It has been accepted for inclusion in Accounting by an authorized administrator of Scholar Commons. For more information, please contact rscroggin@scu.edu. 


\title{
Bankruptcy Probability Changes and the Differential Informativeness of Bond Upgrades and Downgrades
}

\author{
${\text { Yongtae } \mathrm{Kim}^{\mathrm{a}} \text {,*, Sandeep Nabar }}^{\mathrm{b}}$ \\ ${ }^{a}$ Leavey School of Business, Santa Clara University, 500 El Camino Real, Santa Clara, CA \\ 95053, USA \\ b 418 Spears School of Business, Oklahoma State University, OK 74078, USA
}

January 2007

\begin{abstract}
Prior studies have found that stock returns around announcements of bond upgrades are insignificant, but that stock prices respond negatively to announcements of bond downgrades. This asymmetric stock market reaction suggests either that bond downgrades are timelier than upgrades, or that voluntary disclosures by managers preempt upgrades but not downgrades. This study investigates these conjectures by examining changes in firms' probabilities of bankruptcy (assessed using bankruptcy prediction models) and voluntary disclosure activity around rating change announcements. The results indicate that the assessed probability of bankruptcy decreases before bond upgrades, but not after. By contrast, the assessed probability of bankruptcy increases both before and after bond downgrades. We also find that controlling for potential wealth-transfer related rating actions, which can impact stock returns differently, does not alter our results. Tests of press releases and earnings forecasts issued by firms suggest that the differential informativeness of upgrades and downgrades is not caused by differences in prerating change voluntary disclosures by upgraded and downgraded firms. The results support the hypothesis that downgrades are timelier than upgrades.
\end{abstract}

JEL classification: G30; G33; M41

Keywords: Bond rating; Bankruptcy probability; Default risk; Voluntary disclosure

We are grateful to two anonymous referees, Sanjiv Das, Michael Eames, Joseph Piotroski, Patricia O'Brien, and workshop participants at the 2004 American Accounting Association annual meeting for their comments and suggestions. Kim acknowledges financial support provided by the Accounting Development Fund at Santa Clara University.

* Corresponding author. Tel.: +1 408554 4667; fax: +1 4085545193.

E-mail address: y1kim@scu.edu (Y. Kim). 


\section{Bankruptcy Probability Changes and the Differential Informativeness of Bond Upgrades and Downgrades}

\section{Introduction}

Prior studies (e.g., Holthausen and Leftwich, 1986; Hand, Holthausen and Leftwich, 1992; and Goh and Ederingtion, 1993) have found that the stock market responds negatively to announcements of downgrades of firms' bond ratings. However, these studies have found no stock price response to announcements of bond rating upgrades. This evidence suggests that bond downgrades are useful to investors, but bond upgrades have no information content.

Why does the stock market respond differently to bond upgrades and downgrades? Holthausen and Leftwich (1986) offer two potential explanations. First, rating agencies may have asymmetric loss functions, and hence upgrades are not as timely as downgrades. That is, upgrades merely reflect publicly available (favorable) data, whereas downgrades preempt any public release of unfavorable data. Second, firms may be more likely to voluntarily communicate good news to the market than bad news. Hence, the rating agencies' actions may be more informative in the case of downgrades than upgrades.

In this study, we investigate these reasons for the differential stock market response to bond upgrades and downgrades. We test for the differential timeliness of bond upgrades and downgrades by examining changes in firms' probabilities of bankruptcy around revisions of their bond ratings. Bond ratings are intended to capture default risk, and the probability of bankruptcy is a credible proxy for this risk. Following recent improvements in bankruptcy prediction methodology (e.g., Shumway, 2001), we present an analysis of pre- and post-rating revision bankruptcy probability changes, as assessed by a model developed by Chava and Jarrow (2004). 
The results of this analysis, however, are not qualitatively altered if we use one of the other bankruptcy models. We test for differences in the pre-rating change voluntary disclosure activity of upgraded and downgraded firms by comparing the frequency and change in frequency of issuance of press releases and management earnings forecasts by these firms.

The results from the investigation of bankruptcy risk changes indicate that for firms whose bonds are upgraded, there is a significant median reduction in the assessed probability of bankruptcy prior to the rating change. For these firms, there is no change in the assessed probability of bankruptcy after the rating change. However, for firms whose bonds are downgraded, we find significant increases in the assessed probability of bankruptcy both prior to and following the rating change. ${ }^{1}$

Our analysis of press releases and earnings forecasts issued by upgraded and downgraded firms suggests that the differential informativeness of bond upgrades and downgrades is not caused by differences in the pre-rating change voluntary disclosure activity of these firms. The results are consistent with Holthausen and Leftwich's (1986) conjecture that downgrades are timelier than upgrades, and suggest that the rating agencies expend more resources in detecting deterioration in firms' financial prospects than in identifying improvements.

Our results are likely to be helpful to regulators such as the Securities and Exchange Commission (SEC) who recently examine the bond rating agencies' role in the capital markets. The rating agencies have recently come under intense public and regulator scrutiny following the credit default by Enron Corp. Such scrutiny has also occurred in the past after other high-profile financial crises such as those at New York City (in the 1970s), Orange County, and the

\footnotetext{
${ }^{1}$ The stock (and debt) price reaction to rating changes may also be influenced by potential wealth transfers between bondholders and equityholders (e.g., Zaima and McCarthy, 1988; Kliger and Sarig, 2000). With such transfers, a decline (increase) in equity value is possible in response to improvement (deterioration) in debt ratings. Our analysis suggests that wealth-transfer related rating revisions do not impact our results.
} 
Washington Public Power System (SEC, 2003a). Critics of the rating agencies allege that the agencies do not provide timely information about the creditworthiness of companies (SEC, 2003a, page 16), that the agencies move too slowly to be useful to investors, and that they wait too long to downgrade (Zuckerman and Sapsford, 2001; White, 2002). Following congressional hearings on the role of the rating agencies in the Enron collapse (Senate Committee on Governmental Affairs, 3/20/2002), and as directed by the Sarbanes-Oxley Act of 2002, the SEC has launched a review of the level of oversight that should apply to the rating agencies (SEC, 2003b). Our results, while consistent with some of the critics' concerns (we find that neither upgrades nor downgrades are entirely timely), also indicate that downgrades are useful indicators of subsequent deterioration in firms' prospects.

Our study is also related to prior research by Ederington and Goh (1998), who find that stock analysts revise their earnings forecasts in response to both upgrades and downgrades, and Dichev and Piotroski (2001), who find that downgraded firms experience negative stock returns for up to a year following the rating revisions. These studies also find that firm profitability declines subsequent to a downgrade. Our study makes the following contributions to this line of research. First, unlike prior studies that examine the financial analysts' forecasts or behavior of long-term stock returns, we focus on changes in the probability of bankruptcy. Bankruptcy risk is a variable of interest to a broad range of stakeholders - not only investors, but also lenders, creditors, and implicit claimants. ${ }^{2}$ Second, the prior studies do not directly address how well (or poorly) the rating agencies perform their role in the capital markets. An examination of bankruptcy probability changes around ratings revisions allows such an assessment, because bond ratings are intended to convey default risk information. The performance of the rating

\footnotetext{
${ }^{2}$ Holthausen and Watts (2001), among others, suggest that stock returns may not always capture an event's relevance to lenders and creditors.
} 
agencies is a subject of recent regulatory interest, as discussed above. Finally, no prior study has investigated Holthausen and Leftwich's (1986) second hypothesis that the differential informativeness of upgrades and downgrades may be attributable to differences in the pre-rating change voluntary disclosure activity of upgraded and downgraded firms. We conduct such an investigation.

The remainder of this paper is organized as follows. Section 2 contains a description of the sample, and the results of an event study around rating changes. Section 3 discusses the bankruptcy prediction models and presents the empirical tests of changes in firms' probabilities of bankruptcy around revisions of their bond ratings. Section 4 examines differences in the prerating change disclosure behavior of upgraded and downgraded firms. Section 5 presents additional results, and section 6 concludes.

\section{Sample Selection}

\subsection{Sample Selection}

For this study, we obtain bond rating changes from Moody's Default Risk Service database for the years 1980 through 2003, retaining only the most senior issues for multiple concurrent rating changes pertaining to covered firms. The Moody's database yields 6,697 such rating changes, but matching these data with CRSP and Compustat reduces the initial sample size to 2,476. We exclude financial institutions (SIC codes 6000-6999), comprising a total of 514 observations, for consistency with prior research and because the information environment for these firms is unique. We also exclude 535 observations, because we cannot determine fiscal year-ends for these firms. We require fiscal year-ends to align quarterly financial data with the rating change dates. To control for the impact of multiple rating changes issued successively, we retain only rating changes that are not 
followed by a subsequent rating change within one-year period. This procedure eliminates 344 observations. Finally we exclude 335 observations because complete data are not available to compute bankruptcy probabilities. Our test sample thus contains 748 rating changes.

\subsection{Description of Sample and Rating Changes}

Table 1 describes the sample, which contains 238 upgrades and 510 downgrades. In Panel A, we report sample firm characteristics. The statistics in the panel indicate that upgraded firms are larger, more profitable, and have relatively less debt than are downgraded firms. Panel B presents the distribution of the sample over time, as well as the relative proportions of upgrades and downgrades during each year. Both the number of rating changes and the proportion of downgrades are high in the later years. Panel C reports the industry membership of the sample observations based on the Chava and Jarrow (2004) classification scheme. Transportation, communications and utilities firms comprise over half the sample, followed by manufacturing and minerals firms, which are about one-fourth of the sample.

Table 2 presents information on the types of rating changes in the sample. ${ }^{3}$ Ratings of Baa 3 or better are considered investment grade, and a majority of the rating changes in the sample are within investment grade or within speculative grade rating categories. Of the 238 upgrades, 106 are within investment grade rating categories, 92 are within speculative grade rating categories, while 40 are from speculative grade to investment grade. Of the 510 downgrades, 183 are within investment grade rating categories, 289 are within speculative grade rating categories, while 38 are from investment grade to speculative grade. Table 2 also indicates the number of grades by which

\footnotetext{
${ }^{3}$ Moody's did not assign class modifiers $(1,2$, or 3$)$ to its ratings prior to April 20, 1982. For these observations (6 upgrades and 10 downgrades), we code a modifier of 2.
} 
ratings are changed. The sample consists predominantly of one-grade (154 upgrades and 245 downgrades) and two-grade (53 upgrades and 165 downgrades) changes.

\subsection{Stock Price Reaction to Rating Changes}

We first examine abnormal stock returns around the rating changes, to verify conformity with the stock price behavior documented in prior studies. For each sample observation, we compute market model prediction errors over a three-day event window (day -1 through day +1$)$. Following prior research (Holthausen and Leftwich 1986), firm-specific market models are estimated by regressing daily stock returns on the CRSP equally-weighted index over a postrating change estimation period (day +61 through day +315$)$.

Returns data are available on CRSP for 203 upgrade observations and 427 downgrade observations. Consistent with prior studies, we find no evidence of a stock price reaction to bond upgrades. The mean three-day abnormal return around the upgrades is 0.06 percent (statistically insignificant), whereas the median three-day abnormal return is -0.19 percent (statistically insignificant). By contrast, the average stock price response to bond downgrades is significantly negative. The mean three-day abnormal return is -2.68 percent ( $\mathrm{p}$-value $<0.0001$ ), and the median three-day abnormal return is -1.27 percent $(\mathrm{p}$-value $<0.0001)$.

\section{Bond Rating Revisions and Changes in the Probability of Bankruptcy}

\subsection{Bankruptcy Prediction Model}

This study investigates changes in the probability of bankruptcy around bond rating changes. In order to measure the probability of bankruptcy, researchers have historically used Altman's (1968) multiple discriminant analysis model or Ohlson's (1980) conditional logit model. 
In a recent study, Shumway (2001) argues that the extant models produce biased and inconsistent bankruptcy probabilities. He proposes a hazard model that uses both accounting and market information and yields better out-of-sample prediction results than the traditional models. Chava and Jarrow (2004) extend and validate Shumway's research, and also develop a model that uses monthly data and that incorporates industry effects. Chava and Jarrow's (2004) results indicate that the monthly data-based model outperforms the annual models in predicting bankruptcy. Chava and Jarrow's estimation period is 1962-1999, which, unlike previous studies, covers a substantial portion of our sample period (1980-2003). Moreover a monthly data-based model allows us to investigate the informativeness of bond rating revisions over finer time intervals than the annual models. Accordingly, we use the Chava and Jarrow (2004, page 564) monthly model in our analysis. We choose to use their public firm model that utilizes both financial data and marketdriven variables. However, we obtain similar results when we use Chava and Jarrow's (2004) private firm model that utilizes only financial data, or other models such as quarterly versions of the Shumway model or the modified Ohlson model estimated by Hillegeist et al. (2004).

The Chava and Jarrow model for public firms is:

$$
\begin{aligned}
\text { B_Prob } & =\exp (\beta X) /(1+\exp (\beta X)) \\
\beta X=- & 14.8859-1.9236 * N I T A+4.0338 * T L T A-0.4597 * I N D 2-0.0178 * I N D 3 \\
& -1.2260 * I N D 4+0.3414 * N I T A * I N D 2-2.5921 * N I T A * I N D 3 \\
& -3.4877 * N I T A * I N D 4+0.3547 * T L T A * I N D 2-0.3423 * T L T A * I N D 3 \\
& +0.2175 * T L T A * I N D 4-2.26620^{*} \text { EXRET }-0.3475 * R S I Z+0.8312 * \text { SIGMA }
\end{aligned}
$$

where: $B \_$Prob is the estimated bankruptcy probability; NITA equals net income divided by total assets; TLTA equals total liabilities divided by total assets; IND2 equals one for the manufacturing and minerals industries, else $0 ;$ IND3 equals one for the transportation, 
communications and utilities industries, else 0; IND4 equals one for financials and insurance firms, else 0; EXRET equals cumulative monthly returns over twelve months for the firm less cumulative monthly returns for the CRSP value-weighted index; $R S I Z$ equals log of (market capitalization of firm divided by total CRSP market capitalization); SIGMA equals the standard deviation of the residuals from a twelve-month regression of the firm's stock returns on CRSP value-weighted index returns.

In equation (2), both the accounting and market data are lagged by a month so that they are available to the market at the time of the estimate, consistent with Chava and Jarrow (2004). The accounting data are lagged to ensure that quarterly accounting reports' release occurs prior to the month for which bankruptcy probability is estimated. As discussed previously, we exclude financial and insurance firms from our sample. Accordingly, IND4 is coded 0 for all our observations.

\subsection{Descriptive Statistics}

Table 3 provides descriptive statistics on post-rating change B_Probs for our sample. In Panel A, we report the distribution of B_Probs separately for investment grade (Baa3 and better) and speculative grade ( $\mathrm{Ba} 1$ and worse) firms. For investment grade firms, the mean B_Prob following the rating change is 0.0002 , and the median probability is 0.0001 . The corresponding summary measures for speculative grade firms are higher. The mean B_Prob for speculative firms is 0.0491 , whereas the median probability is 0.0009 . These statistics suggest that relatively high bond ratings are associated with relatively low probabilities of bankruptcy, as would be expected.

This inverse relationship between bond rating and probability of bankruptcy is further highlighted in Panel B of the table. In the panel, we examine correlations between revised ratings and B_Probs following the rating change. The ratings are measured from 1 for $\mathrm{C}$ to 21 for Aaa. 
We examine both Pearson and Spearman correlations for the full sample, and also separately for upgrades and downgrades. All correlations in the panel are significantly negative, indicating that the revised ratings and post-rating revision B_Probs are associated negatively.

\subsection{Changes in the Probabilities of Bankruptcy around the Rating Changes}

Table 4 presents the results of our analysis of changes in the estimated probability of bankruptcy for upgrades and downgrades. We report mean and median monthly changes in B_Probs for a seven month test window around the rating revision (month $_{-3}$ through month ${ }_{+3}$ ). Bond upgrades imply a reduced risk of financial distress and hence we expect upgrades to be associated with B_Prob decreases. Similarly, we expect downgrades to be associated with B_Prob increases.

Table 4, Panel A presents results for our full sample consisting of 238 upgrades and 510 downgrades. These results show median decreases in B_Probs in the three months preceding the rating changes for firms whose bonds are upgraded. The B_Prob change is significantly negative

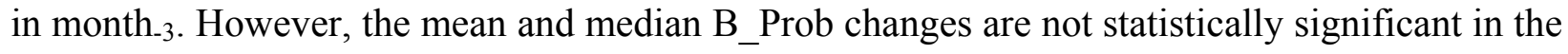
month of and after the upgrade. By contrast, for firms whose bonds are downgraded, B_Probs increase significantly both prior to, and following, the rating revision. In the month immediately preceding the downgrade, the mean B_Prob change is 0.009 (p-value $<0.001$ ). Similarly the mean B_Prob change is 0.0114 (p-value < 0.01) during the downgrade month and $0.0086(\mathrm{p}$ value $<0.01$ ) in the following month.

Debt rating changes may occasionally be indicative of wealth transfers between bondholders and equityholders (e.g., Holthausen and Leftwich, 1986; Zaima and McCarthy, 1988; Goh and Ederington, 1993; Kliger and Sarig, 2000). Such transfers could arise from past or anticipated changes in cash flow variability or leverage. Although factors related to both 
variability and leverage are inputs in the bankruptcy prediction model, we assess the impact of wealth transfer-related ratings revisions on our results as follows. Since downgrades (upgrades) prompted by wealth transfers may favorably (unfavorably) affect equity values, we investigate a sub-sample of firms for which the direction of the rating revision is the same as the direction of the stock price reaction to the revision. This sub-sample presumably excludes the most significant wealth transfer-related rating actions, and is restricted to 101 "good news" upgrades (positive abnormal stock returns in the three-day event window around the rating agency's announcement) and 354 "bad news" downgrades (negative abnormal returns). The results for this sub-sample reported in Panel B of Table 4 are consistent with those for the full sample. For upgrades, the probability of bankruptcy decreases before the rating revision. However downgrades are both preceded and followed by significant increases in the probability of bankruptcy.

The results in Table 4 indicate that neither upgrades nor downgrades are entirely timely, because significant shifts in bankruptcy risk occur prior to both types of rating changes. Unlike upgrades, however, downgrades anticipate subsequent changes in bankruptcy risk. Following a downgrade, the average firm experiences a significant increase in bankruptcy risk following the announcement of the rating change. ${ }^{4}$ The results are thus consistent with the hypothesis that downgrades are timelier and more informative than upgrades.

The results are robust with respect to the choice of models. We replicate our tests with Chava and Jarrow's (2004) private firm model, a quarterly version of the Shumway model, and a quarterly version of Hillegeist et al.'s (2004, table 2) updated Ohlson model (results not tabulated here). For upgrades, we find that the probability of bankruptcy decreases in the months preceding

\footnotetext{
${ }^{4}$ Mean and median probability changes in months beyond +3 are statistically insignificant.
} 
the rating change, but not after the upgrade announcement. By contrast, we find significant increases in the bankruptcy risk of downgraded firms both prior to and following the rating change. These results are qualitatively similar to those presented in Table 4, and the inferences remain the same.

\subsection{The Association Between Stock Returns and Bankruptcy Probability Changes}

The preceding analysis indicates that upgrades are merely reflective of market's perception of previous bankruptcy probability changes, whereas downgrades are indicative of future deterioration in firms' financial prospects. This suggests that the differential stock price reaction to bond upgrades and downgrades is caused by the differential timeliness of upgrades and downgrades. We use regression analysis to examine the relationship between the stock price response to the rating change and bankruptcy probability changes in the months surrounding the rating change:

$$
\begin{aligned}
C A R= & a_{0}+a_{1} \text { Number of Grades }+a_{2} B \_ \text {Prob Change in Month }-3 \\
& +a_{3} B \_ \text {Prob Change in Month } h_{-2}+a_{4} B \_ \text {Prob Change in Month }-1 \\
& +a_{5} B \_ \text {Prob Change in Month } h_{0}+a_{6} B \_ \text {Prob Change in Month }{ }_{+1} \\
& +a_{7} B \_ \text {Prob Change in Month } h_{+2}+a_{8} \text { B_Prob Change in Month }+3+e
\end{aligned}
$$

where: $C A R$ equals the three-day (day -1 through day +1 ) cumulative market model prediction error, Number of Grades equals the number of grades that the rating is revised, computed as the new rating minus the old rating where ratings are measured from 1 for $\mathrm{C}$ to 21 for Aaa, and B_Prob Change in Month $h_{t}$ is computed as the month $\mathrm{t}_{\mathrm{t}}$-end B_Prob minus the month $_{\mathrm{t}-1}$-end B_Prob. ${ }^{5}$

\footnotetext{
${ }^{5}$ For example, when a rating is updated from Baa1 to A2, Number of Grades is 2. Similarly, when a rating is revised from A1 to Baa1, Number of Grades is -3 .
} 
Since an increase in the B_Prob indicates deterioration in the firm's financial position (bad news), we expect a negative relationship between $C A R$ and the B_Prob changes. We include Number of Grades as a control variable in the regression, because the magnitude of the rating change may affect the magnitude of the stock price response. Before discussing the estimation results, we note that the regression is a joint test of (a) the bankruptcy probability model adopted here, and, (b) the relationship between stock returns and bankruptcy probability changes.

Table 5 reports estimation results for equation (3) for the full sample, as well as for the downgrade sub-sample. The results for the full sample indicate that $C A R$ is negatively associated with both lagged and future B_Prob changes. The significant coefficients on the lagged B_Prob change variables suggest that investors delay part of their response to the firm's bankruptcy risk change in the previous months until the firm's debt rating is revised. This delayed reaction may be attributable to costs imposed by implicit stakeholders, who use bond rating actions, rather than other indicators of bankruptcy risk to revise the prices of their claims (Cornell, Landsman, and Shapiro, 1989).

In Table 5, the results for the downgrade sub-sample indicate that $C A R$ is significantly associated with bankruptcy probability changes in months +1 and +2 . This suggests that investors view a downgrade to be informative about the forthcoming deterioration in the firm's financial condition. ${ }^{6}$ Number of Grades has a positive coefficient, indicating that the sharper the downgrade, the more adverse the stock price reaction. We also estimate the regression with an additional control for rating changes across rating grade categories (investment to speculative or speculative to investment), but this variable is statistically insignificant (consistent with

\footnotetext{
${ }^{6}$ Estimation results for alternate specifications (log-transformed variables; rank regressions) are similar to those reported in Table 5 .
} 
Holthausen and Leftwich, 1986), and the significance levels for the other variables are similar to those reported here.

For completeness, we also estimate equation (3) for a sub-sample of upgrades, although these estimation results are not tabulated given the statistically insignificant average stock price reaction to upgrade announcements. Our untabulated results for upgrades are markedly different from those reported above for downgrades. The CAR for upgrades is significantly associated only with B_Prob changes in months -3 and -2 , implying delayed market reaction to a decrease in bankruptcy risk, but not with any of the post-rating revision B_Prob changes.

One limitation of the analysis in Table 5 is that $C A R$ and the estimated bankruptcy probabilities are both computed from stock returns data. However this limitation applies to both the upgrade and the downgrade sub-samples, which nevertheless yield substantially different results. Moreover we obtain qualitatively similar results (not tabulated) when we use prediction models that are based purely on financial statement data (e.g., Chava and Jarrow's (2004) private firm model).

Our results, which support the usefulness of bond downgrades, are not necessarily inconsistent with Dichev and Piotroski's (2001) evidence that the stock returns of downgraded firms continue to be negative for a year following the downgrade announcement. Our regression results suggest that investors view downgrades to be informative signals about bankruptcy probability increases in subsequent months, since the magnitude of the announcement stock returns is a function of these future bankruptcy probability changes. We do not presume our results in Table 5 to imply that the stock market reaction to the signal in the downgrades is complete. Indeed our results in the previous section indicate that downgrades are not perfectly timely, and this constrains their usefulness as well.

Our main results can be summarized as follows. Stock prices react to bond downgrades, but not to bond upgrades. Upgrades and downgrades differ in timeliness, since deterioration in 
firms' bankruptcy probability is evident subsequent to downgrades, but no such post-rating revision shift in bankruptcy risk is evident for upgrades. Moreover the stock price response to the rating revision is associated with subsequent changes in bankruptcy risk for downgrades, but not for upgrades. This suggests that that the differential stock price reaction to upgrades and downgrades is likely reflective of the differential timeliness of these two types of rating changes. The evidence overall is consistent with the hypothesis that the rating agencies have asymmetric loss functions (Holthausen and Leftwich, 1986; as a result of which they expend more resources in detecting deterioration in firms' financial prospects than in detecting improvements, Ederington and Goh, 1998). The results do indicate that downgrades are not entirely timely, since firms' bankruptcy risk also increases prior to the rating revisions.

\section{Voluntary Disclosure by Upgraded and Downgraded Firms}

The preceding analysis suggests that stock prices react to downgrades but not to upgrades because upgrades are associated only with past changes in default risk, whereas downgrades reflect some default risk changes in the periods subsequent to the rating change. In this section, we investigate an alternative explanation for the differential informativeness of upgrades and downgrades: Voluntary disclosures by managers may preempt upgrades but not downgrades (Holthausen and Leftwich, 1986).

We evaluate this conjecture by examining differences in pre-rating revision voluntary disclosures by upgraded and downgraded firms. We perform these tests on two proxies for voluntary disclosure. Following Francis, Philbrick and Schipper (1994), our first proxy for voluntary disclosure is the number of press releases issued by sample firms. Since press releases may occasionally communicate non-financial information, our second proxy is one that focuses exclusively on financial data, the number of management earnings forecasts issued by sample 
firms. $^{7}$ The sample period for this analysis is 1991-2003, since data coverage on our databases is sparse prior to that time. These observations comprise approximately two-thirds of our full sample, as well as of both the upgrade and downgrade sub-samples.

For each disclosure variable, we examine the number of disclosures in the three-month period just prior to the rating change, as well as the change and the percentage change relative to the preceding three-month period. The number of press releases for each sample firm is identified through a search by company name on Business Wire and PR Newswire. Following Bamber and Cheon (1998), management earnings forecasts (point and range) are identified through a search by company name of the following two keyword sets on Business Wire, PR Newswire, and Dow Jones News Service: (1) see(s), expect(s), forecast(s), project(s), estimate(s), higher, and lower; and (2) earnings, income, results, loss, gain, profit(s), improvement, better, and performance.

Table 6 reports the means and medians of the disclosure proxies for the upgrade and downgrade sub-samples, along with significance levels for tests of differences between means ( $t$ test) and medians (Wilcoxon test) for the two sub-samples. In Panel A, we present our analysis of press releases, whereas the results for management earnings forecasts are reported in Panel B.

There is no evidence that upgraded firms voluntarily disclose more prior to the rating action than downgraded firms. In Panel A, the mean (median) number of press releases issued in the three-month period prior to the rating change is 11.24(4) for the upgrade sub-sample and 11.46 (2) for the downgrade sub-sample. ${ }^{8}$ The differences in these averages are not statistically

\footnotetext{
${ }^{7}$ We do not categorize press releases as financial and non-financial, because investors may often use seemingly non-financial disclosures to predict future financial performance. For example, a disclosure about a new product launch could be used to predict future sales or promotion expenses.

${ }^{8}$ By comparison, Francis, Philbrick and Schipper (1994) report annual means (medians) of 25 (18) releases for their at-risk sample and 93 (63) for their shareholder litigations sample (1987-1991).
} 
significant. The means and medians for the change and percentage change variables indicate a slight increase (relative to the preceding three months) in the number of press releases issued for both the average upgraded and downgraded firms. ${ }^{9}$ Again, none of the means or medians statistically differ between the upgrade and downgrade sub-samples.

In Panel B, the mean number of forecasts issued is 0.108 for upgraded firms and 0.221 for downgraded firms. ${ }^{10}$ This difference is significant at the 0.01 level, and is consistent with the high level of disclosure by bad news firms documented in Francis, Philbrick and Schipper (1994) and Skinner (1994). This result, however, runs contrary to the hypothesis that upgraded firms disclose more than downgraded firms. The results for the change and percentage change in the number of forecasts also indicate a higher level of disclosure activity by downgraded firms relative to upgraded firms, but the means and medians of these variables are not significantly different between the two sub-samples.

One limitation of the analysis in Table 6 is that it ignores the content of the disclosures. The nature of the content (good or bad) of the press releases cannot be accurately assessed without a model of market expectations for the data in the disclosures. We do, however, attempt to assess the content of the management earnings forecasts. For each forecast, we compare the manager's earnings prediction to the existing consensus analyst forecast obtained from IBES. Management forecasts that exceed the existing analyst consensus are coded as good news, while those that fall short of the consensus are coded as bad news. Table 7 indicates that the mean number of bad news forecasts issued by downgraded firms $(0.065)$ exceeds the mean number of good news

\footnotetext{
${ }^{9}$ The sample sizes are relatively small for the percentage change variables in the two panels, because we exclude observations with zero disclosures in the denominator.

${ }^{10}$ Skinner (1994) reports an average earnings forecast number of "less than one per firm per year" (1981-1990) whereas Kasznik and Lev (1995) report mean earnings or sales forecasts of 0.094 by good news firms and 0.211 by bad news firms during a 60-day pre-earnings announcement period (1988-1990).
} 
forecasts issued by upgraded firms (0.019). The results of the management forecast content analysis are thus supportive of the evidence in Table 6.

As an additional check, we include the disclosure variables (both separately and together) in the stock returns regression (equation (3)), but none of the coefficients on these variables come out significant (p-values range from 0.41 to 0.97 ), and the other estimation results (not tabulated here)

are similar to those reported in Table 5. These results, together with those reported in Tables 6 and 7, suggest that the differential informativeness of upgrades and downgrades is not attributable to pre-rating change differences in voluntary disclosures by upgraded and downgraded firms.

\section{Additional Analysis on the Informativeness of Rating Changes during 1998-2001}

We lastly investigate the informativeness of bond rating changes during the sub-period 1998-2001. The sample periods of bond ratings studies published recently (e.g., Dichev and Piotroski, 2001) run through the mid-nineties, and more current evidence is relatively sparse. Second, the SEC's (2003c) study of violations of securities laws by accountants and investment professionals, commissioned by the Sarbanes-Oxley Act of 2002, covers the period 1998-2001, consistent with the belief that the performance of financial intermediaries was somewhat lax during the period. Moreover Enron's financial crisis, which focused the public's attention on the rating agencies, occurred in November 2001.

The sub-period sample consists of 54 upgrades and 157 downgrades with complete data necessary to estimate bankruptcy probabilities. Of these 211 rating changes, stock returns are available for 39 upgrades and 98 downgrades. Analysis of the sub-period sample yields the following untabulated results. For upgrades, the mean $C A R$ is $0.54 \%$ (statistically insignificant), whereas the median $C A R$ is $0.06 \%$ (statistically insignificant). For downgrades, the mean $C A R$ is 
$-2.62 \%$ (p-value $<0.01$ ), whereas the median $C A R$ is $-1.26 \%$ (p-value $<0.01)$. None of the mean or median bankruptcy probability changes for the six months -3 through +3 are significant for upgrades. The pattern of probability changes around downgrades is similar to the one reported in table 3 for the full-period sample. Both the mean and median probability changes are positive in months -2 through +1 . The means are statistically significant ( $p$-values range from 0.05 to 0.002 ) in months -2 through +1 . The magnitude of the probability changes is greater for the sub-period than for the full period. For example, the mean probability change in the month ${ }_{+1}$ is 0.0122 for the sub-period sample, compared with 0.0086 for the full-period sample.

Sub-period regression results for equation (3) are also qualitatively similar to the full period results reported in table 5. The coefficient on B_Prob Change in Month ${ }_{+1}$ is somewhat larger in absolute value for the sub-period (downgrades: estimate -1.2682 , t-statistic -2.17 , pvalue $<0.03$ ) than for the full period (downgrades: estimate -0.9623 , t-statistic -4.80 , p-value $<$ 0.01). Overall, the tenor of the results regarding the differential informativeness of upgrades and downgrades is the same for the 1998-2001 sub-period as that for the full period.

\section{Conclusion}

Several studies (e.g., Holthausen and Leftwich, 1986) have found that the stock market

response to bond upgrades and downgrades is asymmetric. Firms' stock prices do not react to announcements of upgrades of their bond ratings, but affected firms' stock returns are negative when rating agencies announce bond downgrades. This suggests either that bond upgrades are not as timely as bond downgrades, or that voluntary disclosures by managers preempt upgrades but not downgrades. This study explores this issue by examining changes in firms' probability of 
bankruptcy (as estimated by the bankruptcy prediction model) and voluntary disclosure activity around bond rating changes.

We find that firms' estimated probability of bankruptcy decreases prior to, but not after, bond upgrades. Thus for upgrades, the rating agencies appear to be reacting to information available to the market prior to the rating action. By contrast, for bond downgrades, we find that firms' estimated probability of bankruptcy significantly increases both before and after the rating changes. We also examine differences in the number of, and change in, press releases and earnings forecasts issued by the managers of upgraded and downgraded firms prior to the rating changes. These tests, while limited by their focus on disclosure quantity rather than content, suggest that the differential informativeness of upgrades and downgrades is not caused by differences in pre-rating change voluntary disclosures by upgraded and downgraded firms. The analysis using the content of management earnings forecasts confirms this conclusion.

The results suggest that downgrades are timelier than upgrades, and that the differential stock price response to upgrades and downgrades is attributable to the differences in the timeliness of the two types of ratings changes. Neither upgrades nor downgrades are entirely timely, however, since significant changes in bankruptcy risk are also evident prior to both kinds of rating revisions. These results should be of interest to the SEC, which recently review the role that bond rating agencies play in the capital markets. 


\section{References}

Altman, E., 1968. Financial ratios, discriminant analysis, and the prediction of corporate bankruptcy. Journal of Finance 23, 589-609.

Bamber, L., Cheon, Y.S., 1998. Discretionary Management Earnings Forecast Disclosures: Antecedents and outcomes associated with forecast venue and forecast specificity choices. Journal of Accounting Research 36, 167-190.

Chava, S., Jarrow, R., A., 2004. Bankruptcy prediction and industry effects. Review of Finance $8,537-569$.

Cornell, B., Landsman, W., Shapiro, A., 1989. Cross-sectional regularities in the response of stock prices to bond rating changes. Journal of Accounting, Auditing, and Finance 4, 460-479.

Dichev, I., 1998. Is the risk of bankruptcy a systematic risk? Journal of Finance 53, 1131-1147.

Dichev, I., Piotroski, J., 2001. The long-run returns following bond rating changes. Journal of Finance 56, 173-203.

Ederington, L., Goh, J., 1998. Bond rating agencies and stock analysts: Who know what when? Journal of Financial and Quantitative Analysis 33, 569-585.

Francis, J., Philbrick, D., Schipper, K., 1994. Shareholder litigation and corporate disclosures. Journal of Accounting Research 32, 137-164.

Goh, J., Ederington, L., 1993. Is a bond rating downgrade bad news, good news, or no news for stockholders? Journal of Finance 48, 2001-2008.

Hand, J., Holthausen, R., Leftwich, R., 1992. The effect of bond rating agency announcements on bond and stock prices. Journal of Finance 47, 733-752.

Hillegeist, S., Keating, E., Cram, D., Lundstedt, K., 2004. Assessing the probability of bankruptcy. Review of Accounting Studies 9, 5-34.

Holthausen, R., Leftwich, R., 1986. The effect of bond rating changes on common stock prices. Journal of Financial Economics 17, 57-89. 
Holthausen, R., Watts, R., 2001. The relevance of the value-relevance literature for financial accounting standard setting. Journal of Accounting and Economics 31, 3-75.

Ip, G., 2002. Companies keep closer eye on accounts - Enron's collapse prompts more clout for raters, less business spending. The Wall Street Journal, February 1, A2.

Kasznik, R., Lev, B., 1995. To warn or not to warn: Management disclosures in the face of an earnings surprise. The Accounting Review 70 (January), 113-134.

Kliger, D., Sarig, O., 2000. The information value of bond ratings. Journal of Finance 55, 2879-2902.

Ohlson, J., 1980. Financial ratios and the probabilistic prediction of bankruptcy. Journal of Accounting Research 18, 109-131.

Securities and Exchange Commission, 2003a. Report on the role and function of credit rating agencies in the operation of the securities markets. Washington, D.C.

Securities and Exchange Commission, 2003b. Concept release: Rating agencies and the use of credit ratings under the federal securities laws. Washington, D.C.

Securities and Exchange Commission, 2003c. Study and report on violations by securities professionals. Washington, D.C.

Shumway, T., 2001. Forecasting bankruptcy more accurately: A simple hazard model. Journal of Business 74, 101-124.

Skinner, D., 1994. Why firms voluntarily disclose bad news, Journal of Accounting Research 3, 38-60.

White, B., 2002. Do rating agencies make the grade? Enron case revives some old issues. The Washington Post January 31, E01.

Zaima, J., McCarthy, J., 1988. The impact of bond rating changes on common stocks and bonds: Tests of the wealth redistribution hypothesis. The Financial Review 23 (4), 483-498.

Zuckerman, G., Sapsford, J., 2001. Why credit agencies didn’t switch off Enron --- S\&P cries 'junk,' but the warning comes too late. The Wall Street Journal November 29, C1. 
TABLE 1

Sample Description

Panel A: Firm Characteristics

\begin{tabular}{|c|c|c|c|c|c|c|c|c|c|}
\hline & & $\begin{array}{l}\text { Combin } \\
\underline{\text { Sample }}\end{array}$ & & & Ipgrades & & & Downgr & des \\
\hline & Mean & Median & Std.Dev & Mean & Median & Std.Dev & Mean & Median & Std.Dev \\
\hline Total Assets (\$million) & 5277.3 & 1326.6 & 17808.2 & 6220.2 & 1773.8 & 19639.8 & 4842.6 & 1026.2 & 16900.8 \\
\hline $\begin{array}{l}\text { Market Value of Equity } \\
\text { (\$million) }\end{array}$ & 2595.1 & 5327.2 & 7329.1 & 3848.8 & 1443.9 & 8462.1 & 2028.2 & 3365.9 & 6687.3 \\
\hline $\begin{array}{l}\text { Book Value of Equity } \\
\text { (\$million) }\end{array}$ & 1339.1 & 364.6 & 3863.9 & 1611.7 & 544.5 & 4685.7 & 1213.4 & 300.8 & 3417.5 \\
\hline Return on Assets & -0.02 & 0.00 & 0.07 & 0.01 & 0.01 & 0.03 & -0.03 & 0.00 & 0.08 \\
\hline Debt-to-Equity & 0.73 & 0.69 & 0.23 & 0.69 & 0.67 & 0.20 & 0.75 & 0.70 & 0.24 \\
\hline
\end{tabular}

The sample consists of 238 upgrades and 510 downgrades. The variables in Panel A are computed at the fiscal year-end prior to the rating change. Market value of equity is stock price multiplied by number of shares outstanding. Return on assets is net income divided by total assets. Debt-to-Equity is total liabilities divided by total assets. 
Panel B: Time distribution

\begin{tabular}{|c|c|c|c|c|c|c|c|}
\hline \multirow[b]{2}{*}{ Year } & \multicolumn{2}{|c|}{ Total } & \multicolumn{2}{|c|}{ Upgrade } & \multicolumn{2}{|c|}{ Downgrade } & \multirow[b]{2}{*}{ Downgrade percent } \\
\hline & Freq & percent & Freq & percent & Freq & percent & \\
\hline 1980 & 5 & 0.67 & 2 & 0.84 & 3 & 0.59 & 60.00 \\
\hline 1981 & 6 & 0.80 & 3 & 1.26 & 3 & 0.59 & 50.00 \\
\hline 1982 & 18 & 2.41 & 6 & 2.52 & 12 & 2.35 & 66.67 \\
\hline 1983 & 29 & 3.88 & 11 & 4.62 & 18 & 3.53 & 62.07 \\
\hline 1984 & 23 & 3.07 & 10 & 4.20 & 13 & 2.55 & 56.52 \\
\hline 1985 & 28 & 3.74 & 9 & 3.78 & 19 & 3.73 & 67.86 \\
\hline 1986 & 33 & 4.41 & 7 & 2.94 & 26 & 5.10 & 78.79 \\
\hline 1987 & 28 & 3.74 & 7 & 2.94 & 21 & 4.12 & 75.00 \\
\hline 1988 & 20 & 2.67 & 7 & 2.94 & 13 & 2.55 & 65.00 \\
\hline 1989 & 33 & 4.41 & 15 & 6.30 & 18 & 3.53 & 54.55 \\
\hline 1990 & 29 & 3.88 & 4 & 1.68 & 25 & 4.90 & 86.21 \\
\hline 1991 & 30 & 4.01 & 11 & 4.62 & 19 & 3.73 & 63.33 \\
\hline 1992 & 23 & 3.07 & 5 & 2.10 & 18 & 3.53 & 78.26 \\
\hline 1993 & 25 & 3.34 & 9 & 3.78 & 16 & 3.14 & 64.00 \\
\hline 1994 & 21 & 2.81 & 8 & 3.36 & 13 & 2.55 & 61.90 \\
\hline 1995 & 26 & 3.48 & 14 & 5.88 & 12 & 2.35 & 46.15 \\
\hline 1996 & 35 & 4.68 & 17 & 7.14 & 18 & 3.53 & 51.43 \\
\hline 1997 & 39 & 5.21 & 25 & 10.50 & 14 & 2.75 & 35.90 \\
\hline 1998 & 55 & 7.35 & 17 & 7.14 & 38 & 7.45 & 69.09 \\
\hline 1999 & 56 & 7.49 & 15 & 6.30 & 41 & 8.04 & 73.21 \\
\hline 2000 & 51 & 6.82 & 16 & 6.72 & 35 & 6.86 & 68.63 \\
\hline 2001 & 62 & 8.29 & 11 & 4.62 & 51 & 10.00 & 82.26 \\
\hline 2002 & 38 & 5.08 & 4 & 1.68 & 34 & 6.67 & 89.47 \\
\hline 2003 & 35 & 4.68 & 5 & 2.10 & 30 & 5.88 & 85.71 \\
\hline
\end{tabular}

Panel C: Industry distribution

\begin{tabular}{|c|c|c|c|c|c|c|c|}
\hline \multirow[b]{2}{*}{ Industry } & \multicolumn{2}{|c|}{ Total } & \multicolumn{2}{|c|}{ Upgrade } & \multicolumn{2}{|c|}{ Downgrade } & \multirow[b]{2}{*}{ Downgrade percent } \\
\hline & Freq & percent & Freq & percent & Freq & percent & \\
\hline Manufacturing and Mineral & 197 & 26.34 & 70 & 29.41 & 127 & 24.90 & 64.45 \\
\hline Transportation, communication, and Utilities & 391 & 52.27 & 107 & 44.96 & 284 & 55.69 & 72.63 \\
\hline Miscellaneous & 160 & 21.39 & 61 & 25.63 & 99 & 19.41 & 61.88 \\
\hline
\end{tabular}


TABLE 2

Matrix of Old and New Ratings

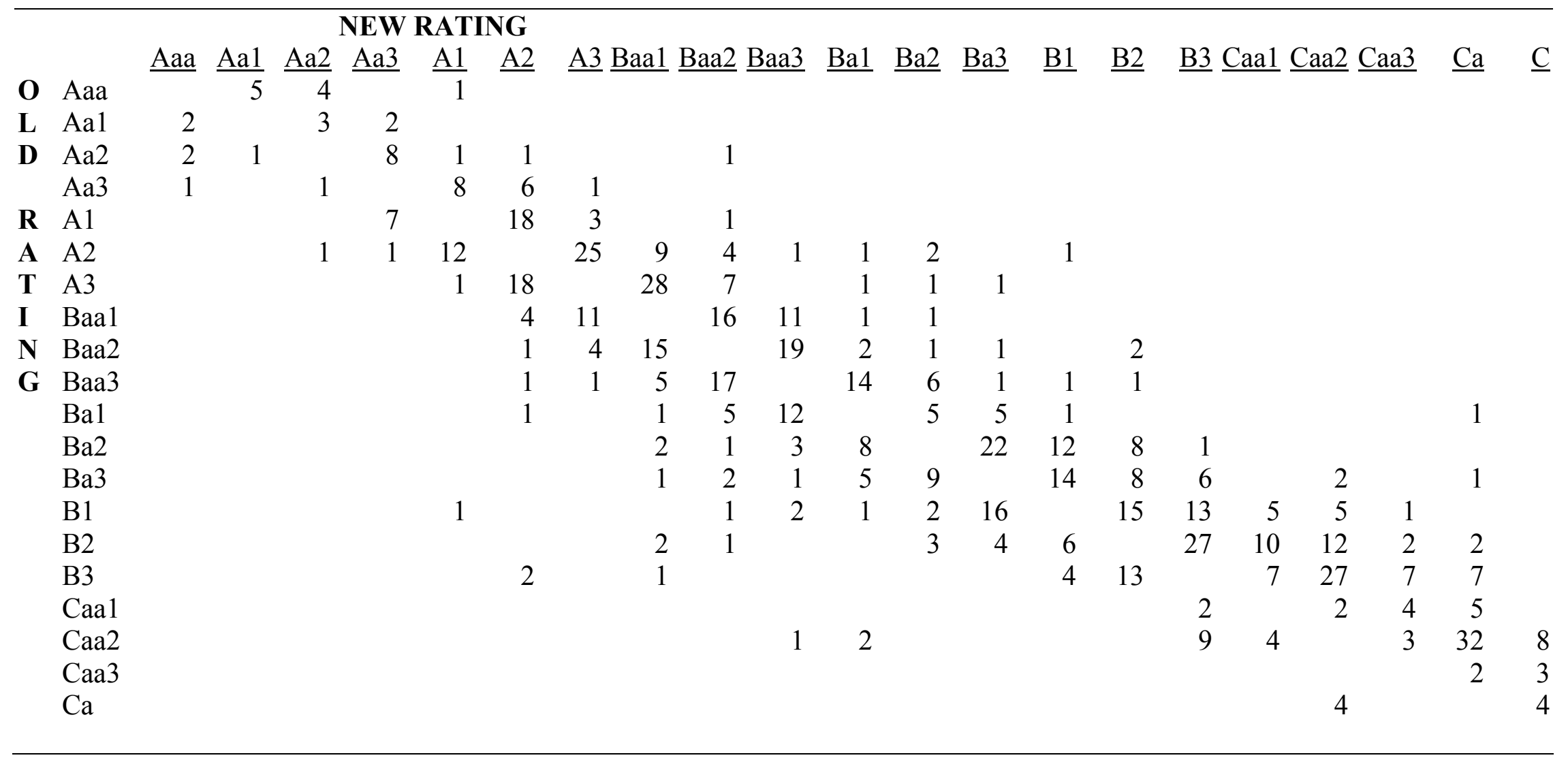

This table summarizes data on old and new bond ratings for a sample of 748 rating changes obtained from Moody's Default Risk Service. The sample consists of 238 upgrades and 510 downgrades. 
TABLE 3

Descriptive Statistics on Post-Rating Change Bankruptcy Probability

Panel A. Sample Distribution

Post-Rating Change B_Probs

Revised Rating Grade

Mean

Median Standard Deviation

Investment (Baa3 and better)

0.0002

0.0001

0.0005

Speculative (Ba1 and worse)

0.0491

0.0009

0.1603

Difference test p-value

0.001

0.001

Panel B. Correlations Between Revised Ratings and Post-Rating Change B_Probs

\begin{tabular}{llcc}
\hline & & & \\
Correlation Type & Sample & Coefficient & P-value \\
\hline Pearson & Full & -0.313 & 0.001 \\
Pearson & Upgrades & -0.196 & 0.01 \\
Pearson & Downgrades & -0.327 & 0.001 \\
& & & \\
Spearman & Full & -0.650 & 0.001 \\
Spearman & Upgrades & -0.229 & 0.001 \\
Spearman & Downgrades & -0.747 & 0.001 \\
& & & \\
\hline
\end{tabular}

These panels present descriptive statistics on sample firms' probabilities of bankruptcy (B_Probs, computed using the Chava and Jarrow model) at the month-end following their bond rating revisions. Panel A presents the distribution of B_Probs, and Panel B presents correlations between the revised ratings, measured from $\overline{1}$ for $\mathrm{C}$ to 21 for Aaa, and B_Probs. In Panel A, difference test p-values are based on two-tailed t-test (Wilcoxon signed rank test) of means (medians). 
TABLE 4

Changes in the Probability of Bankruptcy around Bond Rating Revisions

Panel A: Changes in Probability of Bankruptcy

\begin{tabular}{|c|c|c|c|c|c|c|c|c|}
\hline \multirow[b]{2}{*}{$\begin{array}{l}\text { Month relative } \\
\text { to rating change }\end{array}$} & \multicolumn{4}{|c|}{ Upgrades } & \multicolumn{4}{|c|}{ Downgrades } \\
\hline & Mean & $\begin{array}{c}\text { t-test } \\
\text { p-value }\end{array}$ & Median & $\begin{array}{c}\text { Wilcoxon test } \\
\text { p-value }\end{array}$ & Mean & $\begin{array}{c}\text { t-test } \\
\text { p-value }\end{array}$ & Median & $\begin{array}{c}\text { Wilcoxon test } \\
\text { p-value }\end{array}$ \\
\hline Month $_{-3}$ & 0.000091 & 0.5929 & -0.000003 & 0.0306 & 0.001720 & 0.3769 & 0.000003 & 0.0024 \\
\hline Month $_{-2}$ & 0.000255 & 0.3177 & -0.000001 & 0.2858 & 0.002675 & 0.2016 & 0.000004 & 0.0011 \\
\hline Month-1 $_{-1}$ & 0.000605 & 0.4547 & -0.000001 & 0.1139 & 0.009091 & 0.0001 & 0.000003 & 0.0003 \\
\hline Month $_{0}$ & -0.001179 & 0.3182 & 0.000000 & 0.9740 & 0.011357 & 0.0048 & 0.000003 & 0.0005 \\
\hline Month $_{+1}$ & 0.000016 & 0.1523 & 0.000001 & 0.2628 & 0.008561 & 0.0017 & 0.000004 & 0.0221 \\
\hline Month $_{+2}$ & -0.000006 & 0.6589 & -0.000002 & 0.0868 & 0.001517 & 0.5576 & -0.000002 & 0.8507 \\
\hline Month $_{+3}$ & -0.000006 & 0.7801 & -0.000001 & 0.2859 & 0.000380 & 0.8410 & -0.000004 & 0.0207 \\
\hline
\end{tabular}

Panel B: Changes in Probability of Bankruptcy for Upgrades with Positive Returns and Downgrade with Negative Returns Only

\begin{tabular}{|c|c|c|c|c|c|c|c|c|}
\hline \multirow[b]{2}{*}{$\begin{array}{l}\text { Month relative } \\
\text { to rating change }\end{array}$} & \multicolumn{4}{|c|}{ Upgrades } & \multicolumn{4}{|c|}{ Downgrades } \\
\hline & Mean & $\begin{array}{c}\text { t-test } \\
\text { p-value }\end{array}$ & Median & $\begin{array}{l}\text { Wilcoxon test } \\
\text { p-value }\end{array}$ & Mean & $\begin{array}{c}\text { t-test } \\
\text { p-value }\end{array}$ & Median & $\begin{array}{l}\text { Wilcoxon test } \\
\text { p-value }\end{array}$ \\
\hline Month $_{-3}$ & -0.000101 & 0.5834 & -0.000004 & 0.0064 & 0.003757 & 0.1497 & 0.000001 & 0.0222 \\
\hline Month-2 $_{-2}$ & -0.000119 & 0.2793 & 0.000000 & 0.5720 & 0.002541 & 0.3896 & 0.000006 & 0.0003 \\
\hline Month-1 $_{-1}$ & -0.000041 & 0.0144 & -0.000001 & 0.1360 & 0.009864 & 0.0008 & 0.000003 & 0.0022 \\
\hline Month $_{0}$ & 0.000005 & 0.7789 & 0.000000 & 0.6563 & 0.017173 & 0.0025 & 0.000002 & 0.0040 \\
\hline Month $_{+1}$ & 0.000009 & 0.5926 & 0.000000 & 0.7343 & 0.011943 & 0.0015 & 0.000008 & 0.0001 \\
\hline Month $_{+2}$ & -0.000004 & 0.8504 & -0.000002 & 0.0645 & 0.004772 & 0.1531 & -0.000003 & 0.5068 \\
\hline Month $_{+3}$ & 0.000030 & 0.4230 & 0.000000 & 0.8917 & 0.000962 & 0.7328 & -0.000005 & 0.0802 \\
\hline
\end{tabular}


TABLE 4 continued

This table presents monthly changes in sample firms' probabilities of bankruptcy surrounding the revisions of their bond ratings. Months are indexed relative to the month of the rating change. The probability of bankruptcy is computed using the Chava and Jarrow (2004) public firm model with industry effects. The monthly change in the probability of bankruptcy is computed as the current month-end probability minus the previous month-end probability. P-values indicate significance levels for two-tailed t-tests.

Panel A reports bankruptcy probability changes for a sample of 748 rating changes with 238 upgrades and 510 downgrades. Panel B reports bankruptcy probabilities for a sub-sample for which the direction of the rating revision is the same as the direction of the stock price reaction to the revision. The sub-sample consists of 101 upgrades with positive returns and 354 downgrade with negative returns.

Mean and Medians are in bold if the absolute values are greater than 0.005 . P-values are in bold if they are smaller than $5 \%$. 
TABLE 5

The Association between Stock Returns and Bankruptcy Probability Changes

\begin{tabular}{|c|c|c|}
\hline Variable & $\begin{array}{l}\text { Full Sample } \\
\text { Coefficient } \\
\text { (t-statistic) }\end{array}$ & $\begin{array}{l}\text { Downgrades } \\
\text { Coefficient } \\
\text { (t-statistic) }\end{array}$ \\
\hline Intercept & $\begin{array}{r}-0.0059 \\
(-1.52)\end{array}$ & $\begin{array}{l}0.0039 \\
(0.35)\end{array}$ \\
\hline Number of Grades & $\begin{array}{l}0.0072 * * * \\
(3.51)\end{array}$ & $\begin{array}{l}0.0122^{*} \\
(2.19)\end{array}$ \\
\hline \multicolumn{3}{|l|}{ B_Prob Change } \\
\hline Month $_{-3}$ & $\begin{array}{l}-0.7123 * * \\
(-2.87)\end{array}$ & $\begin{array}{l}-0.6522^{*} \\
(-2.17)\end{array}$ \\
\hline Month $_{-2}$ & $\begin{array}{c}-0.6047 * \\
(-2.02)\end{array}$ & $\begin{array}{r}-0.5089 \\
(-1.39)\end{array}$ \\
\hline Month-1 $_{-1}$ & $\begin{array}{r}-0.1533 \\
(-0.97)\end{array}$ & $\begin{array}{r}-0.1466 \\
(-0.77)\end{array}$ \\
\hline Month $_{0}$ & $\begin{array}{r}-0.3052 \\
(-1.72)\end{array}$ & $\begin{array}{r}-0.3503 \\
(-1.61)\end{array}$ \\
\hline Month $_{+1}$ & $\begin{array}{l}-1.0307 * * * \\
(-6.35)\end{array}$ & $\begin{array}{l}-0.9623 * * * \\
(-4.80)\end{array}$ \\
\hline Month $_{+2}$ & $\begin{array}{l}-0.5216^{* *} \\
(-2.67)\end{array}$ & $\begin{array}{c}-0.5645^{*} \\
(-2.37)\end{array}$ \\
\hline Month $_{+3}$ & $\begin{array}{l}0.2433 \\
(1.28)\end{array}$ & $\begin{array}{l}0.2165 \\
(0.95)\end{array}$ \\
\hline $\begin{array}{l}\mathrm{N} \\
\text { Adjusted } \mathrm{R}^{2}\end{array}$ & $\begin{array}{c}630 \\
19.79 \%\end{array}$ & $\begin{array}{c}427 \\
19.15 \%\end{array}$ \\
\hline
\end{tabular}

This table presents regression results for equation (3):

$\begin{aligned} C A R= & a_{0}+a_{1} \text { Number of Grades }+a_{2} B \_ \text {Prob Change in Month }{ }_{-3} \\ & +a_{3} B \text { Prob Change in Month }-2+a_{4} B \text { Prob Change in Month }-1 \\ & +a_{5} B \_ \text {Prob Change in Month }{ }_{0}+a_{6} B \_ \text {Prob Change in Month }+1 \\ & +a_{7} B \_ \text {Prob Change in Month }{ }_{+2}+a_{8} B \_ \text {Prob Change in Month }{ }_{+3}+e\end{aligned}$

$C A R$ equals the three-day (day -1 through day +1 ) cumulative market model prediction error, Number of Grades equals the number of grades that the rating is revised, where ratings are measured from 1 for $\mathrm{C}$ to 21 for Aaa, and B_Prob Change in Month(t) is computed as the Month(t)-end B_Prob minus the Month(t-1)-end B_Prob.

$* * *, * *, *$ indicate significance at the $0.001,0.01,0.05$ levels respectively. 
TABLE 6

Comparison of Pre-Rating Change Voluntary Disclosures by Upgraded and Downgraded Firms

\begin{tabular}{|c|c|c|c|c|c|c|}
\hline & \multicolumn{2}{|c|}{$\underline{\text { Sub-Sample Mean }}$} & \multicolumn{4}{|c|}{$\underline{\text { Sub-Sample Median }}$} \\
\hline & $\begin{array}{l}\text { Up- } \\
\text { grades }\end{array}$ & $\begin{array}{l}\text { Down- } \\
\text { grades }\end{array}$ & $\begin{array}{l}\text { T-test } \\
\text { p-value }\end{array}$ & $\begin{array}{l}\begin{array}{l}\text { Up- } \\
\text { grades }\end{array} \\
\end{array}$ & $\begin{array}{l}\text { Down- } \\
\text { grades }\end{array}$ & $\begin{array}{l}\text { Wilcoxon } \\
\text { p-value }\end{array}$ \\
\hline \multicolumn{7}{|c|}{ Panel A: Press Releases } \\
\hline $\begin{array}{l}\text { Disclosures } \\
\text { (\# observations) }\end{array}$ & $\begin{array}{l}11.24 \\
(132)\end{array}$ & $\begin{array}{l}11.46 \\
(305)\end{array}$ & 0.93 & 4.00 & 2.00 & 0.69 \\
\hline $\begin{array}{l}\text { Change } \\
\text { (\# observations) }\end{array}$ & $\begin{array}{l}1.47 \\
(132)\end{array}$ & $\begin{array}{l}1.18 \\
(305)\end{array}$ & 0.87 & 0.00 & 0.00 & 0.98 \\
\hline $\begin{array}{l}\% \text { Change } \\
\text { (\# observations) }\end{array}$ & $\begin{array}{l}0.30 \\
(76)\end{array}$ & $\begin{array}{l}0.38 \\
(172)\end{array}$ & 0.58 & 0.08 & 0.00 & 0.79 \\
\hline \multicolumn{7}{|c|}{ Panel B: Management Earnings Forecasts } \\
\hline $\begin{array}{l}\text { Disclosures } \\
\text { (\# observations) }\end{array}$ & $\begin{array}{l}0.108 \\
(157)\end{array}$ & $\begin{array}{l}0.221 \\
(339)\end{array}$ & 0.01 & 0.000 & 0.000 & 0.01 \\
\hline $\begin{array}{l}\text { Change } \\
\text { (\# observations) }\end{array}$ & $\begin{array}{r}-0.032 \\
(157)\end{array}$ & $\begin{array}{l}0.012 \\
(339)\end{array}$ & 0.29 & 0.000 & 0.000 & 0.54 \\
\hline $\begin{array}{l}\% \text { Change } \\
\text { (\# observations) }\end{array}$ & $\begin{array}{l}-0.528 \\
(18)\end{array}$ & $\begin{array}{l}-0.316 \\
(57)\end{array}$ & 0.22 & -1.000 & -0.500 & 0.22 \\
\hline
\end{tabular}

This table presents a comparison of press releases and management earnings forecasts issued by upgraded and downgraded firms. The sample period is 1991 through 2003 . The variables examined are the number, change, and percentage change in each type of disclosure in the three-month period just prior to the bond rating change. The table reports variable means, medians, and significance levels for tests of differences in means/medians for the upgrade and downgrade sub-samples. The number of press releases is identified through a search by company name on Business Wire and PR Newswire. Management earnings forecasts are identified through a search by company name of the following two keyword sets (Bamber and Cheon 1998) on Business Wire, PR Newswire, and Dow Jones News Service: (1) see(s), expect(s), forecast(s), project(s), estimate(s), higher, and lower; and, (2) earnings, income, results, loss, gain, profit(s), improvement, better, performance. Disclosures equals the number of disclosures in the three-month period just prior to the bond rating change, and PrecedingDisclosures is the number of disclosures in the preceding three-month period. Change equals Disclosures minus PrecedingDisclosures. \%Change equals Change scaled by PrecedingDisclosures. 
TABLE 7

Comparison of Pre-Rating Change Management Earnings Forecasts by Upgraded and Downgraded Firms - Bad News and Good News

\begin{tabular}{|c|c|c|c|c|c|c|}
\hline & \multicolumn{3}{|c|}{ Sub-Sample Mean } & \multicolumn{3}{|c|}{$\underline{\text { Sub-Sample Median }}$} \\
\hline & $\begin{array}{l}\text { Up- } \\
\text { grades }\end{array}$ & $\begin{array}{l}\text { Down- } \\
\text { grades }\end{array}$ & $\begin{array}{l}\text { T-test } \\
\text { p-value }\end{array}$ & $\begin{array}{l}\text { Up- } \\
\text { grades }\end{array}$ & $\begin{array}{l}\text { Down- } \\
\text { grades }\end{array}$ & $\begin{array}{l}\text { Wilcoxon } \\
\text { p-value }\end{array}$ \\
\hline \multicolumn{7}{|c|}{ Panel A: Bad News Management Earnings Forecasts } \\
\hline $\begin{array}{l}\text { Disclosures } \\
\text { (\# observations) }\end{array}$ & $\begin{array}{l}0.006 \\
(157)\end{array}$ & $\begin{array}{l}0.065 \\
(339)\end{array}$ & 0.01 & 0.000 & 0.000 & 0.01 \\
\hline $\begin{array}{l}\text { Change } \\
\text { (\# observations) }\end{array}$ & $\begin{array}{l}-0.006 \\
(157)\end{array}$ & $\begin{array}{c}-0.009 \\
(339)\end{array}$ & 0.44 & 0.000 & 0.000 & 0.61 \\
\hline $\begin{array}{l}\text { \%Change } \\
\text { (\# observations) }\end{array}$ & $\begin{array}{l}-1.000 \\
(2)\end{array}$ & $\begin{array}{l}-0.694 \\
(18)\end{array}$ & 0.37 & -1.000 & -1.000 & 0.39 \\
\hline \multicolumn{7}{|c|}{ Panel B: Good News Management Earnings Forecasts } \\
\hline $\begin{array}{l}\text { Disclosures } \\
\text { (\# observations) }\end{array}$ & $\begin{array}{l}0.019 \\
(157)\end{array}$ & $\begin{array}{l}0.003 \\
(339)\end{array}$ & 0.16 & 0.000 & 0.000 & 0.06 \\
\hline $\begin{array}{l}\text { Change } \\
\text { (\# observations) }\end{array}$ & $\begin{array}{l}0.000 \\
(157)\end{array}$ & $\begin{array}{c}-0.006 \\
(339)\end{array}$ & 0.77 & 0.000 & 0.000 & 0.35 \\
\hline $\begin{array}{l}\text { \%Change } \\
\text { (\# observations) }\end{array}$ & $\begin{array}{l}-1.000 \\
(2)\end{array}$ & $\begin{array}{l}-1.000 \\
(3)\end{array}$ & N/A & -1.000 & -1.000 & 1.00 \\
\hline
\end{tabular}

This table presents a comparison of management earnings forecasts issued by upgraded and downgraded firms. The sample period is 1991 through 2003. The variables examined are the number, change, and percentage change in bad news or good news management earnings forecasts in the three-month period just prior to the bond rating change. The table reports variable means, medians, and significance levels for tests of differences in means/medians for the upgrade and downgrade sub-samples. Management earnings forecasts are identified through a search by company name of the following two keyword sets (Bamber and Cheon 1998) on Business Wire, PR Newswire, and Dow Jones News Service: (1) see(s), expect(s), forecast(s), project(s), estimate(s), higher, and lower; and, (2) earnings, income, results, loss, gain, profit(s), improvement, better, performance. Disclosures equals the number of disclosures in the three-month period just prior to the bond rating change, and PrecedingDisclosures is the number of disclosures in the preceding three-month period. Change equals Disclosures minus PrecedingDisclosures. $\%$ Change equals Change scaled by PrecedingDisclosures. Good News and Bad News forecasts are determined based on the comparison of management earnings forecasts and the existing analysts' consensus forecasts obtained from IBES. 